\title{
Mitochondrial DNA depletion syndrome, encephalomyopathic form
}

INSERM

\section{Source}

INSERM. (1999). Orphanet: an online rare disease and orphan drug data base.

Mitochondrial DNA depletion syndrome, encephalomyopathic form. ORPHA:254803

Mitochondrial DNA depletion syndrome, encephalomyopathic form is a group of

mitochondrial DNA maintenance syndrome diseases characterized by predominantly neuromuscular manifestations with typically infantile onset of hypotonia, lactic acidosis, psychomotor delay, progressive hyperkinetic-dystonic movement disorders, external ophtalmoplegia, sensosineural hearing loss, generalized seizures and variable renal tubular dysfunction. It may be associated with a broad range of other clinical features. 